\title{
THE IMMUNE SYSTEM
}

\author{
Paul J. Travers* \\ Anthony Nolan Research Institute, London, UK
}

The immune system is a multilayered series of recognition events and responses whose purpose is to exclude, control or eliminate infectious agents from the body.

The first layer of immunological defence operates at epithelial surfaces, which microorganisms must colonise or breach to be able to establish a focus of infection. Physical barriers and the mechanical movement of pathogens, together with chemical barriers and antimicrobial peptides produced by epithelial cells, make up the first line of defence. Organisms that succeed in crossing an epithelial barrier face elimination by phagocytic cells of the innate immune system, either through direct recognition of common molecular patterns (PAMPs - pathogen associated molecular patterns) by phagocytes or by opsonisation of the microbe by soluble proteins that in turn are bound by receptors on phagocytes. The third layer of immunological defence, that of adaptive immunity, mediated primarily by $\mathrm{B}$ and $\mathrm{T}$ lymphocytes, is induced by dendritic cells, specialised phagocytic cells of the innate response. The antigen receptors of $\mathrm{B}$ and $\mathrm{T}$ lymphocytes are somatically generated and clonally diverse, creating a broad recognition repertoire from which self-reactivity is purged both during the development of the repertoire and during its maintenance. Antibodies, produced by B lymphocytes, both direct opsonins to microbial surfaces, enhancing their uptake by phagocytes, and directly interfere with microbial attachment to cell surfaces, the process of neutralisation. The production of neutralising antibody is perhaps the only effector mechanism which is unique to the adaptive immune system, since $\mathrm{T}$ cell effector mechanisms are derived from more ancestral, innate effector mechanisms. T lymphocyte effector functions eliminate microbes from intracellular sites, with inflammatory $\mathrm{T}$ lymphocytes enhancing the destruction of phagocytosed organisms while cytotoxic T lymphocytes kill infected cells.

The divergence of function of inflammatory and cytotoxic $\mathrm{T}$ cells requires that the immune system ac- quire additional information about the presence of infections, namely where they are in relation to the cell. The cell biology of antigen presentation through MHC class I and class II molecules, and the evolution of the co-receptor molecules, CD4 and CD8, allows this positional information to be presented to the appropriate effector subsets of $\mathrm{T}$ cells.

The complex network of cells that comprises the immune system is coordinated by cytokines and chemokines, a diverse series of growth, survival, differentiation and chemotactic factors that both create the architecture of the immune sysem and orchestrate immune responses in both space and time.

This temporal organisation of the immune response largely reflects the evolutionary divergence of immune recognition and effector mechanisms, with innate responses occurring early on infection and leading to the recruitment of adaptive responses.

Recognition of infectious organisms as 'foreign' relies on two separate strategies. The first - recognition of non-self - is the older in the evolution of the immune system, and consists of the direct recognition of specific molecular patterns present on microorganisms, while the second, more powerful and evolutionarily more recent strategy - recognition of self - relies on recognition mechanisms that are either nonspecific or have a diverse repertoire, coupled with specific inhibition or removal of self-reactivity. Failure to remove or inhibit self-reactivity results in damage to the organism; that this cost is tolerated in evolutionary terms reflects the overall value of these recognition strategies in host defence.

\section{REFERENCE}

JANEWAY JR CA; TRAVERS P; WALPORT M \& SHLOMCHIK, eds. Immunobiology - The Immune systemin health and disease. 6 th ed, Garland Publishing, New York, 2004.

*Deputy Research Director of Anthony Nolan Research Institute, London, UK. 


\title{
CLINICAL AND LABORATORY ASPECTS AND EARLY MARKERS OF THERAPEUTIC EFFICACY IN HUMAN VISCERAL LEISHMANIASIS: A COMPARISON BETWEEN CHILDREN AND ADULTS
}

\author{
AJ Caldas and A Barral \\ Centro de Pesquisas Gonçalo Moniz, Fundação Instituto Oswaldo Cruz, 40295-001, Salvador, BA, Brasil
}

A two-year prospective study was conducted on 23 patients with visceral leishmaniasis (VL), including 14 children and 9 adults, in São Luís-Maranhão, in order to determine clinical and laboratory aspects as well as early markers of therapeutic efficacy in these population before and after treatment. A protocol chart was used for collection of the following data: identification, epidemiological aspects, clinical history, and results of laboratory exams. Immunological profile of VL patients was assessed by measurement of plasma immunoglobulins (IgG, IgG1, IgG2, IgG3, IgG4 and IgE) and cytokines (IFN- $\gamma$, TNF- $\alpha$, IL-10 and IL-12p40) as well as peripheral blood mononuclear cell (PBMC) cytokines (IFN- $\gamma$, TNF- $\alpha$ and IL-10) at day zero, 30, 120 and 210. In addition, Montenegro skin test (MST) and blastogenesis with anti-Leishmania antigen were performed. No significant difference in gender and clinical or epidemiological variables was observed between the two groups. Interestingly, disease duration, adenomegaly and bleedingwere significant present in the adult group, whereas hepatomegaly and mucocutaneous paleness were significant present in the children group. A significant difference between the two groups was found in the percent variation (final values minus initial value divided by initial value) of neutrophil, lymphocytes and erythrocyte sedimentation rate, as well as in the levels of $\mathrm{IgG}, \mathrm{IgG1}$, IgG3 and IgG4. The decrease in IgG and IgG1 levels was marked at 120 days, but remained detectable at the other time points analyzed. The increase in IgG levels appears to be the result of polyclonal B cell activation and the difference observed between the two groups was due to the fact that serum IgG concentrations vary with age. Most patients had detectable IgE levels before treatment, which remained unchanged at the time points studied. A lymphoprolif-erative response was observed in most patients at the end of treatment, and only three children presented a positive MST at 210 days after treatment. This finding can be explained by the fact that the cell population participating in the MST differs from that involved in blastogenesis. Elevated plasma levels of IFN- $\gamma$, IL-10 and IL-12p40 were detected on day zero, with a marked decline being observed at the end of treatment. On the other hand, PBMC levels of IL-10 were high on day zero, while IFN- $\gamma$ was undetectable. Subsequently, IL-10 levels declined and IFN- $\gamma$ increased with advanced treatment. TNF- $\alpha$ was only detected in PBMC cultures after treatment. The results indicate that a favorable therapeutic response leads to an early reduction in the production of both inflammatory and suppressive cytokines in plasma. The cellular immune depression observed in patients with VL might be due to a predominance of the biological activity of IL-10 and not to the lack of IFN- $\gamma$. The high plasma levels of both Th1 type (IFN- $\gamma$, IL-12p40) and Th2 type (IL-10) cytokines on day zero and their decrease at the end of treatment may represent a response parameter for the treatment of human VL.

\section{REFERENCES}

1-BARRAL A \& OLIVEIRA CI. Polymerase chain reaction (PCR) is highly sensitive for diagnosis of mucosal. Acta Tropica, 2004.

2- FAVALI C; COSTA D; AFONSO L; CONCEIÇÃO V; ROSATO A; OLIVEIRA F; COSTA JML; BARRAL A; BARRAL NETTO M \& BRODSKYN CI. Role of co-stimulatory molecules on immune response from patients with tegumentary leishmaniasis. Microbes Infect, 2004.

\footnotetext{
* Pesquisadora titular da Fundação Oswaldo Cruz (FIOCRUZ), Centro de Pesquisas Gonçalo Moniz. Médica formada pela Universidade Federal da Bahia, especializou-se em imunoparasitologia no NIH (EUA) e em parasitologia no Marine Biological Laboratories (EUA). Obteve o título de Doutor em Patologia pela UFBA em 1988. Em 1991, realizou estágio de pós-doutoramento no Seattle Biological Research Institute, SBRI, Estados Unidos.
} 
3- OLIVEIRA CI; TEIXEIRA MJ; GOMES R; BARRAL A \& BRODSKYN CI. Animal models for infectious diseases caused by parasites: Leishmaniasis. Drug Discov Today Disease Models 1: 81-86, 2004.

4- OLIVEIRA CI; TEIXEIRA M J; TEIXEIRA CR; JESUS JR; ROSATO AB; SILVA JS; BRODSKYNICI; BARRAL NETTO M \& BARRAL A. Leishmania braziliensis isolates differing at the genome level display distinctive features in BALB/c mice. Microbes Infect 6: 977-984, 2004.

5- TEIXEIRA MJ; FERNANDES JD; TEIXEIRA CR; ANDRADE BB; POMPEU MML; SILVA JS; BRODSKYN CI; BARRAL NETTO M\& BARRAL A. Distinct courses of cutaneous leishmaniasis are dependent on early chemokine expression patterns. Infect Immun. 2004.

6- COSTA DJ; BARRAL A; FAVALI C; CLARÊNCIO J; AFONSO L; CONCEIÇÃO V; MIRANDA JC; TITUS RG; VALENZUELA J; BARRAL NETTO M; BARRAL A \& BRODSKYN CI. Lutzymyia longipalpis salivary gland homogenate impairs cytokine production and costimulatory molecule expression on human monocytes and dendritic cells. Infect Immun 72: 1298-1305, 2004.

7- ALMEIDA CMC; QUINTANA-FLORES VM; MEDINAACOSTA E; SCHRIEFER A; BARRAL NETTO M \& SILVA WD. Egg yolk anti-bfpA antibodies as a tool for recognizing and identifying enteropathogenic E. coli. Scandinavian J Immun 57: 573-582, 2003.

8- ALMEIDA MC; VILHENA V; BARRAL A \& BARRAL NETTO M. Leishmanial Infection: Analysis of its First Steps. a review. Mem Inst Oswaldo Cruz 98: 861-870, 2003.
9- ALMEIDA MC; CARDOSO SA \& BARRAL NETTO M. Leishmania (Leishmania) chagasi infection alters the expression of cell adhesion and costimulatory molecules on human monocyte and macrophage. Int J Parasitology 33: 153-162, 2003.

10- BAFICA A; OLIVEIRA F; FREITAS LA; NASCIMENTO E \& BARRAL A. American cutaneous Leishmaniasis unresponsive to antimonial drugs: successful treatment using combination of $\mathrm{N}$ methilglucamine antimoniate plus pentoxifylline. Int J Dermatol 42: 203-207, 2003.

11- BARBOSA T; ARRUDA S; FERNANDES BD; CARVALHO LP; CARDOSO S; CUNHA S; BARRETO M; PEREIRA S; RODRIGUES LC \& BARRAL NETTOM. BCG (Bacille of Calmette Guerin) re-vaccination leads to improved in vitro IFN-g response to mycobacterial antigen independent of tuberculin Sensitization in Brazilian School-aged children. Vaccine 21: 2161-2169, 2003.

12- BARRAL A; CALDAS A; COSTA J; GAMA MEA \& RAMOS EAG. Visceral leishmaniasis in pregnancy: a case report. Acta Tropica 88: 39-43, 2003.

13- BRODSKYNI C; OLIVEIRA CI; BARRAL A \& BARRA NETTO M. Vaccines in Leishmaniasis: advances in the last five years. Expert Rev Vaccines 2: 705-713, 2003. 


\title{
UNCONVENTIONAL STRATEGIES FOR THE SUPRESSION OF ALLERGIC ASTHMA
}

\author{
D Sousa Mucida; A Castro-Keller; EC Fernvik \& M Russo* \\ Departamento de Imunologia. Instituto de Ciências Biomédicas. USP \\ CEP 05508-900 - São Paulo - SP, Brazil
}

Over the last 2 to 3 decades, the prevalence of asthma and allergic diseases has increased extensively worldwide. Environmental factors, such as air pollution, allergen exposure and infections, have been associated with the development of atopy, mainly in genetically predisposed individuals.

Asthma is a chronic disease characterized by intermittent and reversible airway obstruction, mucous hypersecretion and airway hyperreactivity (AHR), airway eosinophilia and IgE production. In atopic asthmatic individuals, the interaction between allergens and the immune system leads to activation of $\mathrm{CD} 4^{+} \mathrm{T}$ lymphocytes that secret type 2 cytokines, e.g. IL-4, IL-5 and IL-13, which in turn recruit inflammatory cells to the airway tissue. As a result of the chronic inflammatory process, the airways may suffer profound structural changes referred to as airway remodeling.

The understanding of the pathogenesis of asthma has improved substantially with murine models that have demonstrated a pivotal role for the Th2 lymphocyte-secreted cytokines in the development of the disease. T lymphocytes appear to be a condition sine qua non for asthma development. Actually, T-cell deficient mice (TCR- $\beta$ knock-out (KO)) do not develop asthma-like responses, after immunization and challenge. Moreover, De Sanctis et al. have shown that in non-immunized animals, AHR is strictly $\alpha \beta-T$ cell dependent. In contrast to the conventional $\alpha \beta-T$ cells, $\gamma \delta$-T cells appear to protect against the development of AHR. Indeed, it has been demonstrated that $\gamma \delta$-T cell-deficient animals present increased AHR when compared to wild-type mice. On the other hand, depending on the experimental models used, $\gamma \delta$-T lymphocytes have also been demonstrated to be fundamental for optimal IgE production and airway eosinophilia.
It has been shown that IL-4 and IL-13 are both involved in the production of $\operatorname{IgE}$ and mucous. Furthermore, IL-5 has been demonstrated to be responsible for the growth of eosinophils and their differentiation, survival and activation. It is believed that migration and activation of eosinophils in the lung induce cell damage and are thereby directly associated with the development of AHR. However, murine models of hyperreactivity have demonstrated that depending on mouse strain, the AHR might be more or less dependent on one or another cytokine related to asthma, and thereby associated with different mechanisms. Foster et al. have shown that IL-5 deficiency abolished antigen-induced eosinophilia and the development of AHR. In contrast, Corry et al. reported that IL-4, but not IL5 , is required to activate mast cells by an IgE-dependent pathway and thereby generate AHR. Recently, it has also been demonstrated that animals lacking IL13 , even in the presence of high levels of IL-4 and IL5, do not develop AHR. Moreover, it seems that both IL-4 and IL-13 can exercise a direct effect on the airway cells inducing AHR. Finally, it has been demonstrated that the genetic background of the mouse strain can determine the resistance, susceptibility or even the magnitude of the development of AHR.

Current pharmacotherapies in asthma use corticosteroids and leukotriene antagonists as anti-inflammatory agents and $\beta_{2}$-agonists as bronchodilators to relieve bronchospasms. Other approaches to treat asthma are humanized monoclonal antibodies directed against $\mathrm{T}$ cells, co-stimulatory molecules, type 2 cytokines or IgE antibodies. Although pharmacotherapies have been proven to be effective in controlling asthma symptoms they are not curative. Moreover, persistent treatments might have side effects such as immunosuppression, or exacerbation of Th1 responses that may lead to autoimmunity.

\footnotetext{
* Professor titular no ICB - USP e presidente da Sociedade Brasileira de Imunologia (biênio 2004-2005). Médico formado pela Universidade Federal de São Paulo (UNIFESP), concluiu o doutoramento em Imunologia pela Universidade de São Paulo em 1982. Realizou pós-doutorado no Institute Pasteur em 1986-1987. Obteve livre-docência pela USP em 1994.
} 


\section{REFERENCES}

1-SOUSA MUCIDA D; CASTRO KELLER A; FERNVIK EC \& RUSSO M. Unconventional strategies for the suppression of allergic asthma. Curr Drug Targets Inflamm Allergy 2: 187-195, 2003.

2- RUSSO M; NAHORI MA; LEFORT J; GOMES E; CASTRO KELLER A; RODRIGUES D; RIBEIRO OG; ADRIOUCH S; GALLOIS V; FARIA AM \& VARGAFTIG BB Suppression of asthma-like responses in different mouse strains by oral tolerance. Am J Respir Cell Mol Biol 24: 518-526, 2001.
3- RUSSO M; MARIANO M \& JANCAR S. A new murine model of persistent lung eosinophilic inflammation. Mem Inst Oswaldo Cruz 92: Suppl 2: 215-218, 1997.

4- RUSSO M. Macrôfagos pró e anti-inflamatórios. "Bombeiros piromaniacos". www.sbi.org.br/sbi-narede/ SBInarede12, dezembro/2002.

5- RUSSO M. Não polariza que eu fico doente. www.sbi.org.br/sbi-narede/SBInarede21, setembro/ 2003. 


\title{
OVEREXPRESSION OF THE MINIEXON GENE AND ATTENUATION IN Leishmania
}

\author{
JS Toledo; AFJ dos Santos \& AK Cruz* \\ Departamento de Biologia Celular e Molecular. Faculdade de Medicina de Ribeirão Preto - USP \\ Av. Bandeirantes, 3900, CEP: 14040-904, Ribeirão Preto - SP
}

Kinetoplastid protozoa process their pre-mRNA transcripts into mature mRNA via a bi-molecular transsplicing mechanism; a 39 base capped leader is spliced from the 5' end of the miniexon gene (Splice Leader, $\mathrm{SL}$ ) to the 5' termini of the mRNA. The trans-splicing process is coupled with the 3 'cleavage and polyadenylation events that define the 3 ' termini of mature mRNAs. Therefore, intergenic regions of polycistronic pre-mRNAs are excised and the mRNA molecules are processed into mature competent monocistronic units. The miniexon gene resides as a long tandem array on chromosome 2 of Leishmania. Besides its central role in mRNA maturation the SL gene has been linked to virulence changes associated with amplification/deletion processes observed in chromosome 2 (Spithil, T.W. et al., 1986). In addition, it has been shown that chromosome 2 polymorphism may be due to amplifications or deletions of the tandem array of the miniexon gene (Iovannisci, D. M. et al., 1989).

To understand a possible correlation between virulence and levels of transcription of the miniexon gene we used a recombinant cosmid bearing 100 copies of the SL array to transfect Leishmania major and test the effect of its overexpression in vivo. We have shown that the artificial induction of the miniexon overexpression in L.major reduced the virulence pattern of an originally virulent line (LV39) in BALB/c mice in vivo (Antoniazi, S. et al, 2000). In addition, we investigated the presence of the same phenomenon in L.braziliensis. Hamsters and BALB/c mice were injected in the subcutaneous and intra-dermically, respectively, with L.braziliensis. Those parasites transfected and overexpressing the Miniexon gene in the episome were incapable of inducing lesion in both hosts and conditions tested. L.braziliensis untrans- fected (parental line) and transfectants bearing the backbone of the cosmid vector led to the development of lesions under the same conditions. Transfectant promastigotes show no phenotypic changes, compared to parental line.

We are currently investigating possible mechanisms responsible for the observed phenomenon. One of the lines of investigation is based on previous reports (Lamontagne and Papadoupoulou, 1999) suggesting the existence of a large SL polyadenilated transcript, which is stage-specific in $L$. donovani; this class of SL is only seen in amastigotes. It is possible to speculate that an imbalance of SL made available by the overexpression of the entire gene array could be interfering with amastigote's multiplication or survival. Therefore, we decided to investigate the existence of a developmentally regulated class of polyadenilated SL RNA on attenuated and parental lines, in order to verify a correlation between the polyadenilated SL and virulence levels. For this purpose and based in the architecture of the miniexon gene we designed primers from the intronic region of the miniexon to amplify polyadenilated molecules rescued from a RTPCR. In addition, the availability of a large number of SL transcripts could be modifying the level of mRNAs made available; among them, some would be harmful to amastigotes. Therefore, a global analysis of the gene expression at the protein level was carried out by protein separation using 2D electrophoresis, a high-resolution approach that combines isoelectric focusing and sodium dodecyl sulfate-polyacrylamide gel electrophoresis (IEF/SDS-PAGE). The total protein 2-D gel map of attenuated Leishmania strains was compared to the parental line and the differentially expressed proteins are under investigation.

\footnotetext{
Supported by FAPESP and CNPq.

${ }^{*}$ Completed her undergraduate studies in biomedical sciences in the University of São Paulo, at Ribeirão Preto. After obtaining a Master Degree in the same Institution she conducted a research project at Fundação Instituto Oswaldo Cruz in Rio de Janeiro to obtain her PhD in Genetics at the University of Rio de Janeiro. She conducted her Post Doctoral studies at Harvard Medical School from 1989 to 1992 , working on some aspects of the genetics of the protozoan parasite Leishmania, and this was a period of definition of her future interest in Science. After her Post Doctoral training she returned to the University of São Paulo at Ribeirão Preto to established a laboratory devoted to understand molecular mechanisms and aspects of Leishmania genomic organization central to its biology and parasitism.
} 


\section{REFERENCES}

1- SPITHILL TW \& SAMARAS N. Chromosome size polymorphisms and mapping of tubulin gene loci in Leishmania. In: UCLA SYMPOSIA ON MOLECULAR AND CELLULAR BIOLOGY. Molecular Strategies of Parasitic p. 269-278, 1986.

2- IOVANNISCI DM \& BEVERLEY SM. Structural alterations of chromosome 2 in Leishmania major as evidence for diploidy, including spontaneous amplification of the mini-exon array. Mol Biochem Parasitol 34: 177-188, 1989.
3- ANTONIAZI AS; LIMA HC \& CRUZ AK. Over expression of miniexon gene decreases virulence of Leishmania major in BALB/c mice in vivo. Mol Biochem Parasitol 107, 57-69, 2000.

4-LAMONTAGNE J \&. PAPADOPOULOU B. Developmental regulation of spliced leader RNA gene in Leishmania donovani amastigotes is mediated by specific polyadenylation. J Biol Chem 274: 6602-6609, 1999. 


\title{
RHEUMATIC HEART DISEASE A THROAT POST-STREPTOCOCCAL INFECTION AUTOIMMUNE DISEASE
}

\author{
J Kalil ${ }^{* 1,2,3}$; K Faé ${ }^{1,3}$; SE Oshiro ${ }^{1,3}$, AC Tanaka ${ }^{1}$; PMA Pomerantzeff ${ }^{1} \&$ L Guilherme $^{1,3}$ \\ ${ }^{1}$ Heart Institute - InCor, ${ }^{2}$ Clinical Immunology and Allergy, Department of Clinical Medicine, ${ }^{3}$ Institute for Immunology \\ Investigation, Millenium Institute, University of São Paulo, School of Medicine, São Paulo, Brazil
}

We have shown that heart infiltrating T cells of Rheumatic Heart Disease (RHD) patients were able to recognize both streptococcal M protein peptides (125, 81-103 and 163-177 regions) and myocardium and valvular proteins. Our results allowed us to establish the CD4+ T cell molecular mimicry mechanism between beta hemolytic streptococci and heart tissue proteins in RHD (Guilherme et al, 1995). These results opened several questions involving peripheral and intralesional $\mathrm{T}$ cell recognition, the $\mathrm{T}$ cell receptor (TCR) and the cytokines possibly involved in the development and maintenance of the heart lesions. We verified that the same M5 epitopes cited above were preferentially recognized by peripheral Tlymphocytes and the M5(8196) epitope was preferentially recognized in the context of DR7+ DR53+ molecules in severe RHD patients (Guilherme et al, 2001). These HLA class II alleles were shown to be genetic markers of susceptibility to RF in brazilian patients (Guilherme et al, 1991). Aiming at molecularly identifying heart proteins recognized by peripheral / heart-infiltrating T cells, we found several proteins analyzing heart-derived proteins resolved by 2D-electrophoresis by T cell Western. One (53-kDa pI 5.12) mitral valve protein presented $86 \%$ of mass coverage with vimentin, suggesting that some defined heart antigens are recognized by $\mathrm{B}$ and peripheral and intralesional T lymphocytes.

The cytokine pattern of infiltrating mononuclear cells showed a predominance of proinflammatory cells (TNF- $\alpha$ and IFN- $\gamma$ ) and scarce production of regulatory cytokines, such as IL-4 in the valve tissue. Stimulation of intralesional T cell lines with the M5(81-96) peptide showed that most of these $\mathrm{T}$ cell lines were able to produce IFN- $\gamma$ suggesting a predominant proinflammatory response to this M5 epitope. IL-4 was not produced by mitral valve-derived T cell lines. IL-10 a predominant regulatory cytokine was also secreted by a large numbers of cells in both valve and myocardium tissue as well as by infiltrating $T$ cell lines upon specific streptococcal stimulus, however with low amounts. Taken both in situ and in vitro results, our data showed a mixed pattern of cytokine suggesting the coexistence of intralesional inflammatory and regulatory T lymphocytes. However, such regulatory cells are probably not efficient in neutralizing the aggressive autoreactive $\mathrm{T}$ cells and, consequently, in maintaining immunologic self- tolerance (submitted). The analysis of $\mathrm{T}$ cell repertoire from peripheral and intralesional $\mathrm{T}$ cell lines derived from RHD patients showed normal frequencies of the $24 \mathrm{BV}$ families, excluding the superantigen effect of M protein. Several BVJB oligoclonal expansion was observed, some of which shared between myocardium and mitral valve tissue (Guilherme et al, 2000, 2001). Recently, we described intralesional $\mathrm{T}$ cell clones with a degenerate pattern of reactivity. Five heart-tissue-derived $\mathrm{T}$ cell clones (three from mitral valve and one from myocardium) obtained from one severe RHD patient presented the same TCR-BV13 BJ2S7 with identical CDR3 sequences. They expressed two alpha chains at the RNA level and recognized M5 epitopes or human cardiac beta chain synthetic myosin peptides or mitral valvederived proteins. Interestingly, a mitral valve-derived protein (53-56 kDa/pI7.76) was recognized by two intralesional $\mathrm{T}$ cell clones, one from mitral valve tissue and the other from myocardium. These $\mathrm{T}$ cell clones expressed only one different alpha chain. We also found other $\mathrm{T}$ cell clones that recognized several different antigens bearing the same TCR-BV3 BJ2S1 (Faé et al, 2004). The molecular analysis of $\mathrm{T}$ cell recognition showed an intramolecular degenerate reactivity against streptococcal and human protein epitopes with low homology. In conclusion, all these results create a new picture of the pathogenesis of RHD and could be a prototype of the immune events for other autoimmune diseases. In addition, these data certainly, will open new possibilities of immunotherapy.

*Professor Titular de Imunologia Clinica e Alergia, Departamento de Clínica Médica, Diretor do Laboratório de Imunologia do Instituto do Coração, Faculdade de Medicina da Universidade de São Paulo, Membro Titular da Academia Brasileira de Ciências, Médico formado pela UFRGS em 77, obteve doutorado pela Universidade de Paris 7 em 82, onde trabalhou com Prof Jean Dausset - Prêmio Nobel de Medicina de 80. Em 91, passou um ano como Professor Visitante e Diretor do Laboratório HLA da Universidade de Stanford, EUA. 


\section{REFERENCES}

1-GUILHERME L; WEIDEBACH W; KISS MH; SNITCOWISKY R \& KALIL J. Association of human leucocyte class II antigens with rheumatic fever or rheumatic heart disease in a Brazilian population. Circulation 83: 1995-1998, 1991.

2-GUILHERME L; CUNHA-NETO E; COELHO V; SNITCOWSKY R; PILLEGI F \& KALIL J. Human heartinfiltrating $\mathrm{T}$ cell clones from rheumatic heart disease patients recognize both streptococcal and cardiac proteins. Circulation 92: 415-420, 1995.

3- GUILHERME L; DULPHY N; DOUAY C; COELHO V; CUNHA-NETO E; OSHIRO SE; ASSIS RV; TANAKA AC; POMERANTZEFF PMA; CHARROND; TOUBERT A \& KAILI J. Molecular Evidence for Antigen-driven Immune Responses in Cardiac Lesions of Rheumatic Heart Disease Patients. Int Immunol 12: 1063-1074, 2000.

4- GUILHERME L; OSHIRO SE; FAE KC; CUNHA-NETO E; RENESTO G; GOLDBERG AC; TANAKA AC; POMERANTZEFF PM; KISS MH; SILVA C; GUZMAN F; PATARROYO ME; SOUTHWOOD S; SETTE A \& KALIL J. T-cell reactivity against streptococcal antigens in the periphery mirrors reactivity of heart-infiltrating $\mathrm{T}$ lymphocytes in rheumatic heart disease patients. Infect Immun 69: 5345-5351, 2001.
5- GUILHERME L; CUNHA-NETO E; TANAKA AC; DULPHY N; TOUBERT A \& KALIL J. Heart-directed autoimmunity: the case of Rheumatic Fever. J Autoimmunity 16: 363-67, 2001.

6- GUILHERME L \& KALIL J. Rheumatic fever: the T cell response leading to autoimmune aggression in the heart. Autoimmun $\operatorname{Rev} 1:$ 261-266, 2002.

7- GUILHERME L \& KALIL J. Rheumatic fever: from sore throat to autoimmune heart lesions. Int Arch Allergy Immunol 134: 56-64, 2004.

8- FAÉ K; KALIL J; TOUBERT A \& GUILHERME L. Heart infiltrating $\mathrm{T}$ cell clones from a rheumatic heart disease patient display a common TCR usage and a degenerate antigen recognition pattern. Mol Immunol 40: 1129-1135, 2004.

9- GUILHERME L; CURY P; DEMARCHI LMF; COELHO V; ABEL L; LOPEZ AP; OSHIRO SE; ALIOTTI S; CUNHA-NETO E; POMERANTZEFF PMA; TANAKA AC \& KALIL J. Rheumatic Heart Disease: pro-inflammatory cytokines play a role in the progression and maintenance of valvular lesions. Am J Pathol 2004 (In press). 


\title{
IMMUNE RECONSTITUTION AND IMMUNE RESPONSES IN THE HAEMATOPOIETIC STEM CELL TRANSPLANTED PATIENT
}

\author{
G Aubert; S Rusakiewicz; L McGreavey; P Fallen; H De La Pena; S Nowack; A Knight; R Quartey- \\ Papafio; C Zamoyska; H Forde; IA Dodi \& P Travers
}

Allogeneic haematopoietic stem cell transplantation has been used as a treatment for malignant and non-malignant haematological diseases since 1968. Significant improvements in the outcome for patients suffering from these diseases have been achieved through improvements in chemotherapy and in the transplant procedures themselves. However, significant causes of mortality remain; disease relapse, graftversus-host disease (GvHD) and infections following the transplant are the major complications. These three complications are intimately associated, since the incidence of GvHD is associated with the transfer of mature $\mathrm{T}$ cells with the stem cell graft, yet these $\mathrm{T}$ cells are essential to mediate protection against infection and tumour relapse. The overall benefit of the patient then is a balance between the protective effects of $\mathrm{T}$ cell depletion and the protective effects of retaining at least some effective $\mathrm{T}$ cell immunity. Important questions are therefore to what extent can protective immunity be spontaneously generated in the transplant patient and to what extent can specific or targeted protective immunity be transferred from the donor in the absence of deleterious GvHD responses.

The process of the development and maintenance of the immune repertoire in patients after haematopoietic stem cell transplantation is a combination of expansion of any $T$ cells that have been transferred with the graft. Monitoring the development of specific immune responses, such as those directed against cytomegalovirus, can give a picture both of the general development of specific protective immune responses under different clinical situations, as well as allowing the definition of protective levels of T cells. In the case of individuals who are HLA-A2 ${ }^{+}$, it would appear that around $2 \times 10^{7} \mathrm{CMV}$ specific $\mathrm{T}$ cells per $\mathrm{ml}-$ or about $1-2 \%$ of the circulating pool of CD8 T cells - is required to prevent virus reactivation. The exact levels may vary from HLA type to HLA type, and depend on the nature of the dominant antigen towards which the response is directed. Whether the responding $\mathrm{T}$ cells are derived from memory cells from the donor, or represent a primary response from newly generated naïve $\mathrm{T}$ cells cannot always be determined, though may be inferred in cases where the donor is CMV negative.

More generally, the question of the development of the immune system after a stem cell transplant has been investigated using a combination of phenotypic and molecular markers to differentiate naïve, memory and effector cell populations and to indicate the level of new $\mathrm{T}$ cell production via the thymus. Younger patients, in this case those below the age of 30 years, show a pattern of $\mathrm{T}$ cell development which is dominated by new $\mathrm{T}$ cell production, while older patients show a pattern which is dominated by expansion of peripheral $\mathrm{T}$ cells that have been derived from the graft. The incidence of GvHD also plays an important role in determining the profile of immune reconstitution in patients after transplant, both depleting peripheral $\mathrm{T}$ cell responses and abolishing new $\mathrm{T}$ cell production by the thymus. It is likely that both responses are a consequence of steroid treatment, though a direct inflammatory response in the thymus cannot be eliminated. In the absence of an active thymus, some unusual $\mathrm{T}$ cell populations are seen that may represent homeostatically expanded cells. The impact on the immune status of the patient of these aberrant cell populations is yet to be investigated, but they can be observed at significant levels even after 3 years post transplantation.

While pathogen specific immunity may develop spontaneously in the transplant recipient, it may be more difficult to generate tumour specific immunity. Using as a model system the generation of responses to bcr/able junctional peptides in CML patients we have been able to show that specific peptides can be presented by at least two MHC alleles, A3 and B8, and that both normal individuals and patients appear to be able to generate responses to these peptides. We have developed a novel artificial antigen presentation system to allow us to prime responses to tumour antigens in vitro, and have been able to generate both proliferative and effector responses to bcr/abl junctional peptides. The ultimate goal of this effort is to be able to transfer into the patient a population of tumour specific $\mathrm{T}$ cells that will eliminate the leukaemic cells in the absence of any deleterious GvHD responses. 


\section{REFERENCES}

1-FALLEN PR; McGREAVEY L; MADRIGAL JA; POTTER M; ETHEL M; PRENTICE HG; GUIMARÃES A \& TRAVERS PJ. Factor affecting reconstituion of the $\mathrm{T}$ cell compartment in allogeneic haematopoietic cell transplant recipients. Bone Marrow Transplant 32: 1001-1014, 2003.

2-FALLEN PR;DUARTERF; MCGREAVEY L, POTTER M; ETHEL M; PRENTICE HG; MADRIGAL JA \& TRAVERS PJ. Identification of non-naive CD4+CD45RA+ $T$ cell subsets in adult allogeneic haematopoietic cell transplant recipients. Bone Marrow Transplant 32: 609-616, 2003.
3- AUBERT G; HASSAN-WALKER AF; MADRIGAL JA; EMERY VC; MORTEC; GRACE S; KOH MB; POTTER M; PRENTICE HG; DODI IA \& TRAVERS PJ. Cytomegalovirus-specific cellular immune responses and viremia in recipients of allogeneic stem cell transplants. J Infect Dis 184: 955-963. 2001.

4- PEGGS KS \& MACKINNON S. Immune reconstitution following haematopoetic stem cell transplantation. $\mathbf{B r}$ J Haematol 2004 124: 407-420, 2004. 